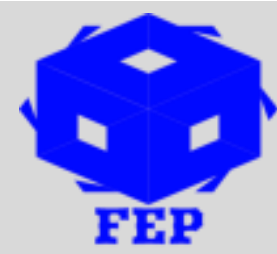

Fair East Publishers

Journal Homepage: www.fepbl.com/index.php/ijarss

\title{
IMPLEMENTATION OF GUIDELINES FOR CCELERATION OF IMPLEMENTATION ESTATE TOURISM EVELOPMENT (CASE STUDY AT LASIANA BEACH, KUPANG CITY, EAST NUSA TENGGARA PROVINCE)
}

\author{
Hartono $^{1}$, Mas Roro Lilik $\mathrm{E}^{2} \&$ Nuhman, $\mathrm{M}^{3}$ \\ ${ }^{1 \& 2}$ Master of Public Administration, Faculty of Social and Political Sciences \\ Hang Tuah University, Surabaya, Indonesia \\ ${ }^{3}$ Master of Public Administration, Faculty of Social and Political Sciences \\ Hang Tuah University, Surabaya, Indonesia
}

\begin{abstract}
*Corresponding Author: Hartono
Corresponding Author Email: susiratna11@gmail.com Article Received: $26-10-21$

Accepted: 15-11-21

Published: 06-12-21

Licensing Details: Author retains the right of this article. The article is distributed under the terms of the Creative Commons Attribution-Non Commercial 4.0 License (http://www.creativecommons.org/licences/by-nc/4.0/) which permits non-commercial use, reproduction and distribution of the work without further permission provided the original work is attributed as specified on the Journal open access page.
\end{abstract}

\begin{abstract}
This study aims to analyze and describe the implementation of the East Nusa Tenggara Governor's Regulation Number 85 of 2019 concerning Guidelines for Accelerating the Implementation of Estate Tourism Development in the Province of East Nusa Tenggara in 2019-2023, especially in Lasiana Beach, Kupang City. By using qualitative research methods with a case study approach. The results of this study indicate that the implementation of the Regulation of the Governor of East Nusa Tenggara has been going well. According to Van Meter Van Horn, there are 6 aspects in the implementation of this Governor's regulation, namely First, the size and objectives of the policy, have been well understood by the implementing staff but there are no clear measures or indicators to assess the implementation process of the Guidelines for Accelerating the Implementation of Estate Tourism Development in the Province of Nusa Southeastern East. Second, resources, from a human and financial perspective, are quite good. Third, the characteristics of the implementing agency/agency, for this factor is also quite good because in carrying out this program, the
\end{abstract}


division of tasks for each employee already exists even though it is not included in the organizational structure. Fourth, the attitude/tendency of the implementers, from this point of view, is good because none of the implementers have rejected this program and has shown their support for this program by the participation of all employees at the Tourism and Creative Economy Office of East Nusa Tenggara Province. Fifth, communication between organizations and implementing activities, this factor is the most crucial in this implementation. It is necessary to improve communication between governments, both the East Nusa Tenggara Provincial Government, the Kupang City Government, the Central Kupang District Government and the Lasiana Village Government. Sixth, the economic, social and political environment, based on the results of research, the social and political environment has a positive effect on the implementation process of this program. Factors supporting the implementation of East Nusa Tenggara Governor Regulation Number 85 of 2019 concerning Guidelines for Accelerating the implementation of estate tourism development in East Nusa Tenggara Province in 2019-2023, especially at Lasiana Beach, Kupang City are the active role of the Government at all levels and the active role of the community in supporting the acceleration program tourism development in Lasiana Beach. Meanwhile, the inhibiting factor for the implementation of the East Nusa Tenggara Governor's Regulation Number 85 of 2019 concerning Guidelines for Accelerating the Implementation of Estate Tourism Development in the Province of East Nusa Tenggara.

Keywords: Implementation of Public Policy, Acceleration of Tourism Development.

\section{INTRODUCTION}

The magnitude of the potential contained, makes tourism development one of the leading sectors to earn income. This is recognized by the World Tourism Organization (WTO) which considers that tourism is an inseparable part of human life, especially regarding social and economic activities (Richardson, 2010). This is supported by a statement from the Ministry of Tourism of the Republic of Indonesia which predicts that in 2019 the tourism sector is the largest foreign exchange earner in Indonesia, amounting to USD 24 billion, surpassing the oil and gas sector, coal and palm oil. In this sector, the impact of incoming foreign exchange can be directly felt by all levels of society. In addition, Indonesia's tourism is targeted to be the best in the region, even through ASEAN. As a maritime country, Indonesia has many potential coastal tourism objects, Indonesia is known for the charm of the sea and its beaches. Indonesia's beaches are one of the most potential tourism sectors, even some beaches in Indonesia have been worldwide, for example the island of Bali and so on.

The beach is the border area between land and sea waters. The definition of this coastal boundary can be found in Law No. 27 of 2007, what is meant by the coastal boundary (boundary) is land along the edge whose width is proportional to the shape and physical condition of the beach, at least 100 meters from the highest high tide point to the west. The beach consists of a sloping beach and a steep beach. A sloping beach is a coast or edge of the sea where the land decreases gradually towards the sea. Law No. 10 of 2009 concerning Tourism states that tourism aims to: (1) increase economic growth, (2) improve people's welfare, (3) eradicate poverty, (4) overcome unemployment, (5) conserve nature, the environment and resources, (6) promote culture, (7) raise the image of the nation, (8) foster a sense of love for water, (9) strengthen national identity and unity and (10) strengthen 
friendship between nations. This can be interpreted that the tourism sector is a sector that has the potential to be developed as a source of income and empowering resources that can contribute to economic development.

The Kupang City Government has also developed policies in the tourism sector, one of which is contained in the Kupang City Regional Regulation No. 12 of 2011 concerning the Detailed Spatial Planning of the Kupang City of 2011-2031. Article 9 of the Regional Regulation states that there is a waterfront city service system with the concept of a Waterfront City by completing facilities and infrastructure in the tourism sector to support the concept of a seaside city based on environmental balance and sustainability. Regional Regulation Number 12 of 2011 concerning the Detailed Spatial Planning of Kupang City for 2011-2031 is a form of support from the Kupang City Government in developing the tourism sector in Kupang City, including the development of Lasiana Beach tourism. The tourism development consists of the construction of road infrastructure to the Lasiana beach resort, the construction of decent lodging, the existence of good restaurants and the existence of shops selling souvenirs for tourists. Important factors in the development of coastal tourism include unspoiled natural conditions, the diversity of flora and fauna and the coastal ecosystem. Coastal tourism is part of coastal tourism that uses the beach as a tourist attraction. Kupang City is the capital of East Nusa Tenggara Province, as well as the largest city on Timor Island, which is located on the coast of Kupang Bay, northwest of Timor Island. As the largest city in the province of East Nusa Tenggara, Kupang City is filled with various ethnic groups.

The acceleration of tourism development in the Province of NTT, as stated in the Regional Medium-Term Development Plan (RPJMD) of the Province of NTT for 2018-2023 is directed to the conception of estate tourism. This is in line with the Strategic Plan of the Kupang City Tourism and Culture Office. David Pandie (kompasiana.com) explained that the concept of estate tourism is a tourism development concept which includes all services and their environment. The completeness of tourism in question consists of 5 A's, namely Attractions, Access, Accommodation, Ammenity and Awareness. The 5 A conception shows the readiness of tourism destinations in meeting the needs of tourists. As a destination for the Estate program, Lasiana Beach is known for its beautiful panorama, Lasiana Beach has an area of about 3.5 hectares of land. The Lasiana Beach area is overgrown with coconut trees and palm trees that beautify the scenery on the coast. Currently Lasiana Beach is managed by the Kupang City Government and is intensively innovating the estate program. Policy on road access, infrastructure as well as facilities and infrastructure are under development projects. The problems that arise at Lasiana Beach are hygiene issues such as dirty bathrooms and untidy drains. However, this research is interesting to discuss, considering the condition of natural beauty on Lasiana Beach which is associated with the Government's efforts to increase revenue from the tourism sector with estate programs based on creative economy, tourist villages and local wisdom.

\section{LITERATURE REVIEW}

\section{Tourism Development Policy}

a. Main Policies, 1) Accommodate, build and also develop the potential benefits of tourism as an economic activity that can create jobs. 2). Improving the capabilities and skills of the apparatus as well as empowering the tasks and functions of the organization rather than as a regulator facilitator which can become tourism development. 3). Increase business 
opportunities and one's involvement in developing tourist areas. 4). Delivering tourism cooperation between regions and also the business world.

b. Spatial Policy (spatial) Tourism, 1). Provide clear direction so that it can become tourism development based on spatial characteristics through development zoning. 2). For ease of development and processing, what needs to be done is the grouping of tourist attraction objects in the Tourism Area Unit (SKW). These tourist area units are areas that have tourist activity centers so that they have circuit links or tourist routes. 3). To prioritize the development of tourist area units by taking into account their impact on the development of objects and tourist attractions.

c. Policy for Development of Tourist Attractions and Objects. 1). The development of tourist objects and attractions concerning aspects of utilization and control of one another is an integrated unit, therefore the development of tourist objects and attractions must be in accordance with the basics of the planning system. 2). The development of tourist objects and attractions is carried out on the basis of an approach to the development of the Tourism Kawaan Unit with nuances of religious values, aesthetic culture and morals adopted by the community. 3). The development of tourism objects and attractions is carried out in accordance with market mechanisms and includes nature tourism, cultural tourism, special interest tourism, beach tourism and adventure tourism.

d. Tourism Facilities and Infrastructure Development Policy, 1). Prepare the planning system for the Spatial Planning of the Tourism Area. 2). Improve accessibility to tourist areas. 3). Fulfillment of standard facilities (health facilities, security, cleanliness, communication) in tourist areas as needed. 4). Attract investors to build accommodation and other supporting facilities.

\section{Tourism Infrastructure}

Infrastructures are all facilities that can enable the economic process to run smoothly in such a way that it makes it easier for humans to fulfill their own needs. Tourism infrastructure is a natural resource as well as human resources that can be absolutely needed by tourists on their way to tourist destinations, such as roads, electricity, water, telecommunications, terminals, bridges, and so on. Suwantoro (2004)

\section{Tourism Facilities}

Tourism infrastructure is all facilities that allow tourism infrastructure to live and develop and can provide services to tourists who visit tourist attractions and also meet their diverse needs. Tourism facilities are the completeness of tourist destinations that are needed to serve the needs of tourists while enjoying their tour (Suwantoro: 2004). The development of tourist facilities in tourist destinations and certain tourist objects must be adapted to tourism needs both quantitatively and qualitatively. Tourism facilities qualitatively indicate the number of tourist facilities that must be provided, and quantitatively which shows the quality of services that have been provided and which is reflected in the satisfaction of tourists who receive services. In relation to the types of tourism advice services in tourist destinations, a standard tourist standard has been prepared, both nationally and internationally, so that the provision of tourism facilities is only a matter of choosing or determining the type and quality to be provided. According to Lothar A. Kreck in (Yoeti, 1996) Facilities for tourism products are all forms of companies that can provide services to tourists. For example ; (a) in the field of tourism services, such as: travel agents, travel agents, tour guides, conventions, intensive trips 
and exhibitions, tourism consultants, tourism information; (b) tourism facilities business sector consisting of: accommodation, restaurants, bars, tourist transportation and so on.

\section{Tourism Goals and Benefits}

Tourism is a business activity in serving the needs or fulfilling the desires of a tourist who will start or is on a tour. According to Oka A. Yoeti in his book "Introduction to Tourism Science" which states that: "Tourism is a temporary trip that is held from one place to another with the intention not to try or to earn a living in the place visited but simply to enjoy sightseeing and recreation or to fulfill various desires." After we know the various definitions of "Tourism" from various sources, it has made it easier for us all to understand what tourism is without feeling hesitant to apply it in social life.

\section{Estate Tourism Development at Lesiana Beach}

Marine tourism is all activities carried out to create fun, challenges, new experiences, health that can only be done in the water area. Maritime tourism with a meaningful impression is not merely getting entertainment from various attractions and natural treats of the coastal and oceanic environment, but it is also expected that tourists can participate directly in developing environmental conservation as well as a deep understanding of the ins and outs of coastal ecosystems so as to form awareness of how to behave to protect the environment. preserve coastal areas in the present and in the future. This type of tourism that utilizes coastal areas and oceans directly or indirectly is very popular not only in Indonesia but also throughout the world. The beach has been open to the public since the 1970s and began to attract more international tourists after the local government built a number of facilities in 1986.

The NTT Provincial Government under the leadership of the Governor and Deputy Governor for the 2018-2023 period plans to open and develop as many as 21 new estate tourism destinations in the NTT Province. The opening and development of this new estate tourism destination is planned to be completed within five years of the leadership of the Governor and Deputy Governor of NTT, Viktor B. Laiskodat - Josef Nae Soi, who revised the previous target, namely in the first three years of his leadership (https://www.bpsdmd.nttprov. go.id/node/398). One of the estate tourism destinations is Lasiana Beach. This is based on the NTT Governor's Regulation Number 85 of 2019 which was issued on October 28, 2019, regarding the development of tourism estate in East Nusa Tenggara Province. The development of tourism in the Province of NTT, as stated in the Regional Medium-Term Development Plan (RPJMD) of the Province of NTT for 2018-2023, is directed to the conception of estate tourism. David Pandie explained that the concept of estate tourism is a concept of tourism development which includes all services and their environment.

The completeness of tourism in question consists of 5 A's, namely Attractions, Access, Accommodation, Amenitis and Awareness. The 5 A conception shows the readiness of tourism destinations in meeting the needs of tourists. In article 6 of this NTT Governor Regulation it is explained that the Acceleration of Estate Tourism development is carried out with the following activities; (a) fulfillment of attraction needs; (b) fulfillment of accessibility needs; (c) fulfillment of accommodation; (d) fulfillment of amenities; (e) fulfillment of awareness. Article 7 of the Governor's Regulation explains that the estate tourism development activities as intended consist of; (a) development and arrangement of tourism institutions through strengthening Tourism Awareness Groups in Estate Tourism Areas in fulfilling standardization and service quality; (b) synchronizing activities and building 
partnerships between universities and tourism institutions in providing education in the tourism sector; (c) integration of estate tourism as a provincial strategic development area into planning and spatial planning documents; (d) investment development and improvement of the skill level of local workers in tourism in the management of regional creative industries based on local potentials; (e) Establishment of a tourism information center and promotion of regional strategic tourism objects; (f) the use of potential natural and cultural tourism resources of special interest in an integrated manner through estate tourism products; $(\mathrm{g})$ increasing the number and quality of various physical and non-physical infrastructures supporting the tourism sector; (h) opening sea shipping routes connecting islands in the Region to create unity in the Ring of Beauty.

\section{RESEARCH METHOD}

The type of research used in this thesis is qualitative research. Qualitative research method is a research process/procedure that aims to collect, describe and analyze descriptive data in the form of writing, expressions and observed human behavior (Islamy, 2005). Research that uses qualitative methods with a case study approach (Cresswell, 2018) because first, the phenomenon of estate tourism development on Lasiana Beach in Kupang City, NTT Province is a unique phenomenon, moreover, it is still quite rarely studied by researchers in Indonesia. Second, the concept of estate tourism is an integrated tourism concept, which so far has been successfully implemented in tourist areas in Indonesia, such as Bali or Jogjakarta with a variety of complete tourism infrastructure facilities. But what if the concept of estate tourism is applied in NTT, which incidentally lacks adequate tourism infrastructure? This question makes researchers interested in studying research with this theme, so that researchers can make interpretations and analyzes to describe the government's role in accelerating the development of tourism estate on Lasiana Beach, Kupang City, East Nusa Tenggara Province.

\section{RESULTS AND DISCUSSION}

\section{Human Resources}

The Head of the East Nusa Tenggara Province Tourism and Creative Economy Agency confirmed that the existence of these three resources was the key to the successful implementation of Governor Regulation number 85 of 2019 concerning guidelines for accelerating the implementation of estate tourism development on Lasiana Beach, Kupang City, East Nusa Tenggara. That the correlation of estate tourism development with Lasiana beach is community-based tourism which provides opportunities for people who are involved in creative economic activities and tourism industry activities. It is expected to improve the community's economy and support the acceleration of income for the poor. The development of an integrated and dynamic tourism industrial area will be able to provide rapid economic growth in employment opportunities, incomes and an increase in living standards in activating the industrial sector. Estate tourism is also built in order to support the development of ring of beauty tourism. With the construction of estate tourism areas throughout the Regency/City area, there will be competitiveness and attractiveness. Lasiana Beach can be believed to be a source of regional and community economics, this can be seen by traders who carry out economic activities, meetings held by government agencies and private institutions, the existence of levies from visits by domestic tourists, foreign tourists. 


\section{Characteristics of Implementing Organizations}

The focus of attention on implementing agencies includes formal organizations and nonformal organizations that will be involved in implementing public policies. This is very important because the performance of (public) policy implementation will be very much influenced by the right characteristics and match the role of the implementing agent. In addition, the scope or area of policy implementation needs to be taken into account when determining the implementing agent, the larger the agent involved should be. In addition to being related to technical characteristics, according to Van Meter and Van Horn there must be a match between the competence of the implementer and the position placed. For this aspect, the researcher did not conduct interviews related to the competence of each actor because there were no appropriate indicators if an interview was conducted, so the researcher conducted a literature study on the competencies possessed by each implementer. In looking at the characteristics of implementing agencies, as stated by van Meter and van Horn, then this discussion cannot be separated from the bureaucratic structure. Bureaucratic structure is defined as the characteristics, norms and patterns of relationships that occur repeatedly in executive bodies that have both potential and real relationships with what they have by carrying out policies.

\section{Attitude (Disposition) of the Implementers}

The attitude of acceptance or rejection of the implementing (agent) will greatly affect the success or failure of the implementation of public policy. This is very likely to happen because the policies implemented are not the result of the formulation of local residents who are well acquainted with the problems and problems they feel. However, the policy that will be implemented by the implementer is a "top down" policy where it is very possible that the decision makers do not know (even cannot touch) the needs, desires or problems that citizens want to solve.

It is important for implementers to understand the general objectives as well as the basic measures and objectives of the policy. Successful policy implementation must be followed by a thorough awareness of the policy. This means that the failure of a policy implementation is often caused by the disobedience of the implementers to the policy. In this condition, individual perception plays a role. The policy implementers at Lasiana Beach, Kupang City as implementing organizations have known and understood the Standards and Objectives of this policy, but in practice this understanding is only carried out by a few people. This means that the implementers themselves have different points of view about its implementation even though the service officers have known and understood the Standards and Objectives of implementation in accelerating the implementation of the development of tourism estate on Lasiana Beach, Kupang City, East Nusa Tenggara.

\section{Communication between Implementing Organizations}

In order for public policy to be implemented effectively, according to Van Horn and Van Metter, what is the standard goal must be understood by individuals (Implementators). Those who are responsible for achieving the standards and objectives of the policy, therefore the standards and objectives must be communicated to the implementers. Communication in the framework of delivering information to policy implementers about what are the standards and objectives must be consistent and uniform (Consistency and uniformity) from various sources of information. Coordination is a powerful mechanism in the implementation of public policy, 
the better the coordination of communication between the parties involved in an implementation process, the assumption is that errors will be very small, and vice versa. The government believes that Lasiana Beach can be used as a source of regional and community economics, this can be seen by traders who carry out economic activities, meetings held by government agencies and private institutions, levies from visits by domestic tourists, foreign tourists. The facilities available at the Lasiana beach tourism object include: main stage, lopolopo (relaxing place) tracking, break watter (breakwater), public toilets, monitoring substation, parking area, Wifi, and canteen. Lasiana beach tourism also contributes to the increase in Kupang City's PAD, which is Rp. 5.000.000,- (five million rupiah). This can be seen from the number of visitors from year to year has increased. Until now, the government has always optimized the development of tourism estate on Lasiana beach with promotions through social media, TVRI. Likewise, the infrastructure facilities that are needed by visitors, improve services immediately.

\section{Social, Economic and Political Environment}

The results in the field show that the community's response to the existence of Lasiana Beach is quite good. The community supports the potential of Lasiana Beach to be developed into a tourist destination that provides benefits for the Government and the community in Kupang City. The results of interviews with resource persons from Lasiana beach visitors, Erres Nagi, S.Sos., M.Sc. TVRI Kupang employees on November 29, 2020 at Lasiana beach at: 13.30-14.00 WITA showed that the existence of Lasiana Beach was very well known to the residents of Kupang City. The price of admission at Lasiana Beach is quite cheap and affordable, namely a children's ticket of Rp. 2,000, - (two thousand rupiah) adult ticket Rp. 3,000, - (three thousand rupiah) motorcycle parking fee of Rp. 3,000, - (three thousand rupiah) and parking fees for 4 (four) wheeled vehicles Rp. 5,000, - (five thousand rupiah). Knowing the Lasiana beach tourist attraction, information from friends and word of mouth because they are local residents so they are very familyers for the people of Kupang city. Eres Nagi visited Lasiana beach because it is close, access from the highway to the location is very easy, ticket prices are cheap and can be entertained by the beach atmosphere to relieve fatigue. Transportation to the beach location can use public transportation or private vehicles.

It is hoped that the development of tourism estate on Lasiana beach will increase PAD and increase income for the surrounding community. While the minus side of the development of tourism estate requires a lot of money to make improvements. In terms of adding facilities, it is necessary to provide more trash cans, have cleaners and promote the habit of throwing garbage in its place. as well as affordable food prices and cheap ticket prices for the beauty of the beach and fresh free air. However, the facilities provided are still inadequate and need to be improved, including trash cans and children's games. The plus point of developing Lasiana beach into a tourism estate is that it is not too far from the city of Kupang, access from the highway is not too far and its strategic location is located on the border between the City and Kupang Regency.

Meanwhile, the negative value of developing Lasiana beach tourism must be balanced with adequate facilities and infrastructure and a good arrangement because it is adjacent to residential areas. It is hoped that the NTT Provincial Tourism and Creative Economy Office will improve road infrastructure to tourist attractions and add facilities. The cleanliness of 
the beach and surrounding areas needs to be improved by adding trash bins and urging visitors to throw garbage in the available places and there is also a need for cleaning staff. There should be more education about the socialization by the government it will improve the quality of human resources that are more advanced and better. The participation of the local community is involved in maintaining and maintaining existing facilities from disturbance by irresponsible people. From the economic side of the community, the existence of Lasiana beach has helped the economy of the community around Lasiana Village, Kupang District, Kupang City.

\section{Factors Supporting Policy Implementation}

Based on the analysis and theoretical study that the supporting factor for the implementation of the Lasiana Beach development policy is the active participation of the Government, both the East Nusa Tenggara Provincial Government, the Kupang City Government, the Central Kupang District Government and the Lasiana Village Government. Also, the community supports the government's program on accelerating the implementation of estate tourism development in Lasiana Beach.

\section{Obstacles to Policy Implementation}

According to Sunggono(1994) in the book "Law and Public Policy", policy implementation has several inhibiting factors, namely: First, the content of the policy implementation failed because the content of the policy was still unclear, meaning that the objectives were not detailed enough, the means and implementation of priorities, or policy programs are too general or non-existent. Second, because of the lack of internal and external provisions of the policies to be implemented. Third, the policies to be implemented may also indicate significant deficiencies. Fourth, other causes of failure to implement a public policy can occur due to deficiencies involving auxiliary resources, for example those concerning time, cost/funds and human labor. Second, Information. The implementation of public policy assumes that the role holders who are directly involved have information that is necessary or very relevant to be able to play their role properly. This information does not exist, for example due to communication disorders. Third, support. The implementation of a public policy will be very difficult if the implementation is not enough support for the implementation of the policy. Fourth, the sharing of potential. The reasons related to the failure of the implementation of a public policy are also determined by the aspect of potential sharing among the actors involved in the implementation.

\section{CONCLUSION}

Based on the results of research and discussion, it can be concluded that, in general, the implementation of East Nusa Tenggara Governor Regulation Number 85 of 2019 concerning Guidelines for Accelerating the Implementation of Estate Tourism Development in the Province of East Nusa Tenggara in 2019-2023, especially on Lasiana Beach, Kupang City has gone well. . Aspects in the implementation of the Governor's regulation can be explained as follows; 1). The size and objectives of the policy, the policy objectives are well understood by the implementing staff but there are no clear measures or indicators to assess the implementation process of the Guidelines for the Acceleration of the Implementation of Estate Tourism Development in the Province of East Nusa Tenggara. 2). Resources, when viewed from human resources and financial resources are quite good. 3). The characteristics of the implementing agency/agency, for this factor are also quite good because in carrying 
out this program, the division of tasks for each employee already exists even though it is not included in the organizational structure. 4). The attitude / tendency of the implementers, from this point of view, is good because there are no implementers who reject this program and show their support for this program by the participation of all employees at the Tourism Office and the Creative economy of East Nusa Tenggara Province. 5). Communication between organizations and implementing activities, this factor is the most crucial in this implementation. It is necessary to improve communication between governments, both the East Nusa Tenggara Provincial Government, the Kupang City Government, the Central Kupang District Government and the Lasiana Village Government. 6). The economic, social and political environment, based on the results of research on the social and political environment, have a positive effect on the implementation process of this program. 7). Factors supporting the implementation of East Nusa Tenggara Governor Regulation Number 85 of 2019 concerning Guidelines for Accelerating the implementation of estate tourism development in East Nusa Tenggara Province in 2019-2023, especially at Lasiana Beach, Kupang City are the active role of the Government at all levels and the active role of the community in supporting the acceleration program tourism development in Lasiana Beach. 8). The inhibiting factor for the implementation of the East Nusa Tenggara Governor's Regulation Number 85 of 2019 concerning Guidelines for Accelerating the Implementation of Estate Tourism Development in the Province of East Nusa Tenggara in 2019-2023, especially at Lasiana Beach, Kupang City, is the lack of clear regulations governing the distribution of tourism potential between the Nusa Tenggara Provincial Government. East and Kupang City Government.

\section{References}

Budi, W. (2005). Public Policy: Theory and Process. Revised Edition, Media Presindo. Yogyakarta.

Bungin, B. (2001). Social Research Methodology: Quantitative and Qualitative Formats. Airlangga University Press, Surabaya.

Darnanik, L., \& Weber, H. F. (2006). Ecotourism Planning. Yogyakarta: Pusbar Ugm \& Andi Yogyakarta

Hasnil, P. (2006). Efforts to Increase Blitar City's Original Revenue Through Implementation of Blitar City Regulation Number 4 of 2004 (Thesis, Public Administration) I1mu Study Program, Universitas Brawijaya Malang.

Moleong, J. (2006). (Revised Edition), Qualitative Research Methodology. PT Remaja Rosdakarya, Bandung.

Pitana, R. G., \& Gayatri, (2005). Sociology of Tourism. Bandung: Andi. Spillane, J. Law No. 10 of 2009 concerning Tourism

Jaundry, P. (2015). Ecotourism Economic Valuation of the Development of Coastal Tourism Objects (Case Study of Non-Market Environmental Services Natural Resources Lasiana Coastal Tourism Objects, Kelapa Lima District, Kupang City, NTT Province. Journal of Environmental Science, 13.

Karina, W. S., \& Argyo, D. (2018). Maritime Tourism Development (Descriptive Study on Marine Tourism Development Actors Watukarung Beach, Watukarung Village, 
Pringkuku District, Pacitan Regency. Journal of Development and Social Change, 1(1).

Marasabessy, T. (2014). Implementation of Capital Relocation Policy in Government Administration. Journal of Regional Government Administration, 4(1st Edition). Jakarta: IPDN.

Maria (2018). Attributes of Social Media-Based Marketing Tourism and Tourist Satisfaction at Lasiana Beach Kupang. Journal of Assets, 20(1).

Nurisyah, S. (1998). Physical development plan for Marine Tourism Areas in Indonesian Coastal Areas. Indonesian Parks and Landscapes Bulletin. Planning, Design and Management, 3(2).

Obed, O. (2017). The Effectiveness of the Use of Vehicle Parking Land at the Lasiana Beach Tourism Object Kupang which has an impact on increasing the income of the community and the local government of the Kupang Municipality. Journal of Civil Engineering, 2(1).

Sunarto (2001). Kupang Bay Beach Conservation, East Nusa Tenggara. Journal of Indonesian Geographical Magazine, 5(1).

Syul, R.S. (2014). Development of Lasiana Beach Tourism Potential as Sustainable Tourism in Kupang City, NIT Province. Journal of Tourism Destinations, 2(1).

Tri, R.R., Heru, A.A., \& Fitria, R. (2016). Marine Tourism Development Strategy in Padang City. Journal of Management and Entrepreneurship, 7(1).

Yulianda, F. (2007). Marine Ecotourism as an Alternative Utilization of Conservation-Based Coastal Resources. Presented at the Science Seminar on February 21, 2007 at the Department of Water Resources Management, FPIK. IPB 